\title{
Air gasification of digestate and its co-gasification with residual biomass in a pilot scale rotary kiln
}

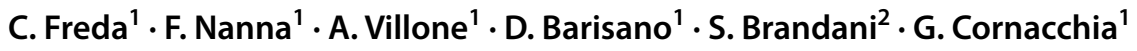

Received: 19 December 2018 / Accepted: 17 June 2019 / Published online: 4 July 2019

(c) The Author(s) 2019

\begin{abstract}
In this study energy recovery of digestate from a biogas plant was investigated via air gasification. Gasification tests were executed in a pilot scale rotary kiln plant having a nominal biomass feeding rate of about $20 \mathrm{~kg} / \mathrm{h}$. The equivalence ratio was varied from 0.22 to 0.39 with the goal to approach the autothermal condition. Tests were carried out for $5 \mathrm{~h}$ in steady state condition. Syngas composition, char and gas yields were measured. To improve the cold gas efficiency of the process, a mixture of digestate and almond shells $(60: 40 \mathrm{wt} \%)$ was gasified. Autothermal condition was reached with the mixture using equivalence ratio of 0.30 where the corresponding cold gas efficiency achieved the maximum value of 55\%. The raw gas had a lower heating value of $4-5 \mathrm{MJ} / \mathrm{Nm}^{3}$. To evaluate possible improvements in the produced gas properties, in this work the effect of steam injection was also investigated.
\end{abstract}

Keywords Equivalence ratio $\cdot$ Raw gas $\cdot$ Cold gas efficiency $\cdot$ Autothermal gasification $\cdot$ Simulation $\cdot$ Co-gasification

\section{Introduction}

The anaerobic digestion (AD) process breaks down biodegradable material such as biomass, manure and organic fraction of MSW, in the absence of oxygen by microorganisms [1-4]. The main product of AD is biogas that is used to produce heat and power. The wet byproduct stream remaining at the end of the process is called digestate. It usually contains macroelements such as nitrogen, phosphorous, potassium, calcium, sulphur, magnesium; recalcitrant organic molecules such as lignin, cutin, humic acids, complex proteins [5] which allow to consider it as valuable substitute, with lower environmental impact, of synthetic fertilizers. To improve the quality of the digestate as fertilizer, a composting stage can be executed. Aerobic bacteria oxidize the ammoniacal nitrogen to nitrites and aerobic microorganisms degrade the recalcitrant macromolecules $[6,7]$. The global compost production in Europe is estimated at 12-15 MTon/year [7]. Digestate is often widespread in agricultural fields near the

$\triangle$ C. Freda

cesare.freda@enea.it

1 ENEA, Laboratory of Thermochemical Processes for Wastes and Biomass Valorization, SS Jonica $106 \mathrm{~km} \mathrm{419+500,}$ 75026 Rotondella, MT, Italy

2 Ladurner srl, Via Innsbruck, 33, 39100 Bolzano, Italy site where it is produced, unfortunately this is not always the optimal strategy as it could cause soil and water pollution, namely eutrophication, under specific condition. Its water content is about $90 \mathrm{wt} \%$, so that moving it at any distance using trucks is expensive. Therefore, planning how to manage the digestate waste is a crucial task when a biogas plant is to be realized, especially when spreading in agricultural land is not possible [8]. In anaerobic digestion the major limitation is usually the feedstock incomplete conversion. Quite often in fact up to $50 \%$ of the organic matter remains unconverted [9]. Thence about half of the energy remains in the digestate, making it a promising fuel for energy production [10].

To exploit the energy content of the digestate, thermochemical process such as combustion, gasification, pyrolysis could be considered. Pedrazzi et al. tested digestate as fuel in a wood pellet furnace of $29 \mathrm{~kW}_{\mathrm{th}}$. They had problems related to the ash sintering. In fact, they observed formation of agglomerates, which obstruct the brazier holes and smother the combustion. These issues were avoided in co-combustion of dry digestate with wood at $50 \mathrm{wt} \%$ [11]. Pyrolysis of digestate was investigated in laboratory scale [12-14]. Coupling anaerobic digestion with pyrolysis generates several bioenergy carriers such as: biogas and biomethane from $\mathrm{AD}$; biochar, bio-oil, and raw gas from pyrolysis. Nevertheless, a circular process about the coupling of anaerobic digestion 
with pyrolysis was not clearly developed and some strategic hurdles still have to be overcome, i.e., the fate of bio-oil and biochar. A valuable fate for the biochar should be its use as a soil fertilizer, but its effects on the plant growth are variable and it remains unclear if and when this option is prosecutable [15]. Bio-oil is a complex mixture of organic compounds and water, it is chemically reactive, it is not stable over time, its $\mathrm{pH}$ is low (2-3) [16]. All these characteristics severely limit its applications [17].

Under this point of view, compared to pyrolysis, air gasification has less drawbacks. Specifically, with respect to the process products, only syngas and char are produced, while the unstable and acid fraction of bio-oil is absent; it is autothermal since the thermal energy to sustain the process is provided by a partial combustion of the organic matter occurring during the process of gasification itself. Wiśniewski et al. gasified digestate at $850{ }^{\circ} \mathrm{C}$ with use of $\mathrm{CO}_{2}$ as gasifying agent in a batch reactor electrically heated. Gasification test run for $1500 \mathrm{~s}$, along this time syngas composition was measured, and the corresponding gas heating value was found to be $3.7 \mathrm{MJ} / \mathrm{Nm}_{\text {dry }}^{3}$ [8]. Nanna et al. gasified digestate in a continuous bench scale rotary kiln by $\mathrm{CO}_{2}$, steam and mix of them at $800{ }^{\circ} \mathrm{C}$. The mass rate of digestate was about $0.7 \mathrm{~kg} / \mathrm{h}$. Its conversion was about $60 \mathrm{wt} \%$. The authors identified some actions to improve the process, such as: extending the residence time of the solid in the reactor, prolonging the interaction of the solid with the reactive gas and co-gasifying the digestate with residual biomass [18]. Chen et al. gasified at laboratory scale digestate with high ash content in an electrically heated downdraft fixed bed gasifier. Slagging issues were not observed. The optimum temperature was $800^{\circ} \mathrm{C}$. Cold gas efficiency had its maximum of $67 \%$ at $0.28 \mathrm{ER}$. Tar content decreased from $6.48 \mathrm{~g} / \mathrm{Nm}_{\text {dry }}^{3}$ to $1.61 \mathrm{~g} / \mathrm{Nm}_{\text {dry }}^{3}$ with ER varying from 0.25 to 0.30 [19]. Gnanendra et al. gasified digester waste (ash content 9-11 wt\%) in an open top gasifier coupled with an internal combustion engine. The digester waste mass rate was $40 \mathrm{~kg} / \mathrm{h}$. The reactor was able to handle the high ash content present in the fuel. Engine operation indicated that gas quality was consistent with specific fuel consumption of $1.6 \mathrm{~kg} /$ $\mathrm{kWh}$ amounting to an overall electrical efficiency of $15 \%$ [20]. One of the concerns in digestate gasification is the high ash content. In fact, ash decreases the heating value of the fuel; it is chemically inert during the process but requires heat to reach the gasification temperature, so that a higher fraction of the organic matter has to be burnt. Furthermore, slagging phenomena could occur in the hot spots of the gasifier.

Rotary kilns are reliable in thermochemical processes of waste and biomass as they allow a good mixing of the solid that ensures a radial uniformity of temperature and a continuous discharge of the process ashes [21-24]. The uniformity of temperature prevents slagging and clinkering; the continuous discharge of the produced ashes fits with the high ash composition of the digestate. Therefore, in this study the digestate gasification in a rotary kiln was tested. The interesting novelties of this work compared to the available literature are:

The rotary kiln reactor is a pilot scale having a nominal feeding mass rate of $20 \mathrm{~kg} / \mathrm{h}$; the size of this plant is particularly meaningful for the further development at industrial scale; autothermal digestate air gasification was targeted in the rotary kiln plant, to avoid external energy supply and to recover syngas suitable for heat and power; a theoretical simulation study was carried out to identify plant engineering solutions that could improve process efficiency. However, it should be specified that the activities presented in this work were intended as a preliminary approach. Under this perspective, tests aimed at evaluating the energy sustainability of the process at the most promising operating conditions were arranged. The collection of experimental data was mainly targeted at acquiring information about cold gas efficiency, permanent gas compositions and yields. No work was instead devoted, at this stage, to the characterization of organic and inorganic gas contaminants load. The authors are aware that gas cleaning issues, especially those related to tar content, are crucial aspects in gasification process, and are, therefore, determined to deal with these features in a next and more focused work.

\section{Materials and methods}

In accordance with the objective of the work aimed at assessing the energy performance of the digestate gasification process, the experimental tests were first carried out by injecting air as gasifying agent to approach the autothermal conditions. To evaluate possible overall improvements of the process, tests of co-gasification with biomass and addition of steam were later considered. Specifically, as biomass cofeedstock almond shells were selected.

Almond shells are in fact an interesting biomass feedstock for thermochemical processes since they have a relative low ash content and a relatively high volatile matter and heating values. Moreover, they are easily transportable by the screw feeder system. As known, a successful feeding of biomass is a very crucial aspect in biomass thermochemical processes since during this stage, biomass could show problematic behavior. Biomass feeding is for instance difficult when its particle size is not suited, biomass moisture content is high and feeding system design is poor. The as produced digestate is usually a sludge which, if used as it is, could give serious problem in screw feeding system. Additionally, due to the high humidity content ( $>60 \mathrm{wt} \%$ ) its direct use would make difficult to keep the required high process temperature. 
Therefore, feedstocks pre-treatments, such as drying and pelletizing, are strongly advised. On the contrary almond shells do not give feeding problems. Finally, it was yet investigated in biomass gasification with good results by several authors [25-29].

\section{Feedstocks characterization}

About $1000 \mathrm{~kg}$ of dried digestate from an anaerobic digestion plant for biogas production were provided by the Italian company Ladurner srl. This biogas plant works with fermentable wastes, such as organic fraction of municipal solid waste, sewage sludge and lignocellulosic biomass.

The digestate was provided to the authors in the form of pellets of $1 \mathrm{~cm}$ in diameter and of $3 \mathrm{~cm}$ in length, approximatively. About $1000 \mathrm{~kg}$ of almond shells were provided by an Italian producer and packer of almonds. Their linear dimension was about $2-3 \mathrm{~cm}$.

The feedstocks were thoroughly analyzed as concerns proximate and ultimate analysis, bulk density and heating values. The samples for the analyses were prepared according to UNI EN 14778. The ultimate analysis on dry basis was carried out with a CHNS MICRO Cube analyser by Elementar, oxygen was calculated by difference. The heating value was measured by an IKA Werke Bomb Calorimeter.

In Table 1 the results of the chemical-physical analyses are reported together with the corresponding reference method. The humidity content of digestate pellets provided to ENEA was found to be very close to biomass feedstocks used in thermochemical processes, i.e., about $10 \mathrm{wt} \%$.

As expected, the ash content of digestate was higher compared to lignocellulosic biomass (i.e., $32 \mathrm{wt} \%$ vs $1.65 \mathrm{wt} \%$ ), in fact the ash of the original fermentable feedstock that went to the plant for biogas production was concentrated by the loss of gas and volatile molecules that occurred during the process of anaerobic digestion [30].

Nevertheless, despite to this first stage of treatment, the recovered digestate showed volatile matter content and a heating value still sufficiently high to make it exploitable in a process of gasification.

\section{Rotary kiln plant}

The pilot scale rotary kiln plant is composed of a feeding system for feedstock, the rotary kiln reactor and a cleaning system of raw gas. The feeding system consists of a hopper having a capacity of $1 \mathrm{~m}^{3}$. It is equipped with a vibrator to break the material bridges that could be formed during the feeding. A horizontal feeding screw shifts the digestate pellets from the hopper to a sloping screw that moves the digestate to a star valve and then to the injection screw of the rotary kiln reactor. The injection screw is cooled to avoid uncontrolled thermochemical phenomena of the supplied feedstock that could create plugs and blocks of the feeding system. Nitrogen is injected to the star valve and injection screw to create an inert atmosphere nearby the reactor. The rotary kiln reactor is made in AISI 310 stainless steel. Its length and diameter are 3 and $0.3 \mathrm{~m}$, respectively. Its rotational speed can be increased up to $5 \mathrm{rpm}$, while its slope can be increased up to $10^{\circ}$. It can be electrically heated by three resistances, the total electrical power of which is $70 \mathrm{~kW}$, they are used during the start-up stage and endothermic chemical processes. The sealing of the rotary kiln is realized for each of the two reactor

Table 1 Chemical and physical analyses of digestate pellets and almond shells

\begin{tabular}{llll}
\hline & Digestate pellets & Almond shells & \\
\hline Proximate analysis, wt\% (dry basis) & & \\
Ash & $32 \pm 4$ & $1.65 \pm 0.08$ & UNI EN 14775 \\
Volatile matter & $55 \pm 5$ & $77.9 \pm 0.8$ & UNI EN 15148 mod. ASTM D3175 \\
Fixed carbon & $13 \pm 3$ & $20.5 \pm 0.8$ & \\
Ultimate analysis, wt\% (dry basis) & & & \\
$\mathrm{C}$ & $35.0 \pm 1.9$ & $47.8 \pm 1.4$ & UNI EN 15104 \\
$\mathrm{H}$ & $4.00 \pm 0.19$ & $6.4 \pm 0.2$ & \\
$\mathrm{~N}$ & $3.07 \pm 0.18$ & $0.44 \pm 0.01$ & \\
$\mathrm{O}$ & $24.6 \pm 1.9$ & $43.7 \pm 1.4$ & \\
$\mathrm{~S}$ & $0.87 \pm 0.09$ & $0.028 \pm 0.001$ & \\
$\mathrm{Cl}$ & $0.10 \pm 0.01$ & $0.018 \pm 0.001$ & \\
Humidity, wt\% ${ }_{\text {as received }}$ & $9.9 \pm 0.5$ & $9.0 \pm 0.4$ & UNI EN 14774-1 \\
Bulk density, $\mathrm{kg} / \mathrm{m}^{3}$ as received & $440 \pm 40$ & $410 \pm 30$ & UNI EN 15103 \\
Heating value, $\mathrm{MJ} / \mathrm{kg}$ dry feedst. & & & \\
Higher heating value (HHV) & $13.7 \pm 0.2$ & $20.2 \pm 0.2$ & \\
Lower heating value (LHV) & $12.7 \pm 0.2$ & $18.7 \pm 0.2$ & UNI EN 14918; ISO 1928; DIN 51900 \\
\hline
\end{tabular}


flanges by a system of three rubbing graphite gaskets. To avoid their thermal degradation and process gas leakages the gaskets are kept under a flow of nitrogen. The reactor is equipped with three thermocouples to measure the temperature along the reactor axis: the first one is nearby the feedstock feeding point, the second one is in the middle of the reactor, and the last one is approximatively near the discharge area of char. The pressure in the rotary kiln reactor is measured by two manometer gauges installed at the feedstock feeding area and at the discharge of char. Gasifying agents are injected at the head of the reactor and they concurrently cross it with the feedstock. The solid product, after crossing the oven, falls into a reservoir while the gas enters the cleaning section.

The sensible heat of the raw gas from the kiln overheats by a heat exchanger the gasifying agent. The raw gas is mixed with a $\mathrm{CaO}$ and activated carbon powder; it gets into a bag filter at about $180{ }^{\circ} \mathrm{C}$. The powder sticks to the bags and creates a cake that contains tar and particulate. When the pressure drop upstream and downstream of the bag filter is higher than $5 \mathrm{hPa}$, nitrogen is injected in countercurrent to the raw gas path and the cake of powder fine particles and tar falls down. The output gas gets at $100-150{ }^{\circ} \mathrm{C}$ in an indirect heat exchanger where most of water and condensable organic molecules are condensed. After the condenser, the gas crosses two scrubbers: the first one works with alkaline solution of sodium hydroxide to remove acid gas such as $\mathrm{HCl}$ and $\mathrm{H}_{2} \mathrm{~S}$; the second one works with water for a further purification. Downstream of this scrubber, a blower sucks the gas. Then, the gas crosses a volumetric gas meter after which it goes to the torch, where it is burnt. A gas flow rate of $11 / \mathrm{min}$ is sucked, downstream of the gas meter, by a gas chromatograph 3000A Agilent, to measure the volumetric composition of hydrogen, carbon monoxide, carbon dioxide, methane and light hydrocarbons in the produced gas. Measurements of nitrogen and oxygen are also included. For this gas analysis, the gas chromatograph system (GC) is equipped with two molecular sieve columns (i.e., Molsieve $5 \mathrm{~A}$ and Paraplot Q), working in parallel, and a thermoconductive detector (TDC). As carrier gas, argon is used.

\section{Experimental method}

The gasification tests of digestate pellets and its mixture with almond shells at 60:40 wt $\%$ were carried out according to the method described below.

About $150 \mathrm{~kg}$ of feedstock were loaded in the hopper. Kiln slope was fixed at $3^{\circ}$ in all the tests. Rotational speed and air rate are set at the values presented in Table 2. Kiln sealing, star valve and injection screw were all purged with nitrogen. The blower downstream of the cleaning section was regulated to have a depression in the rotary kiln of 1-5 $\mathrm{hPa}$. The rotary kiln was heated electrically up to the gasification temperature at a rate of $3-5{ }^{\circ} \mathrm{C} / \mathrm{min}$. After having approached the gasification temperature, feedstock feeding started and the electrical heating was reduced. Tests were carried out for about $5 \mathrm{~h}$ at steady state. In air/steam gasification tests a liquefied petroleum gas (LPG) boiler was used to generate steam. During the test, the dry produced gas was measured by the volumetric gas meter and its composition was analyzed by the GC-TCD system every $3 \mathrm{~min}$. To end the tests both the feedstock feeding and the air supply were stopped and nitrogen was injected into the rotary kiln. The char present in the kiln after stopping the test was discharged into an auxiliary tank. When the reactor reached room temperature, rotational speed and auxiliary fluids were all shut down. The chars in the reservoir and in the auxiliary tank were then collected and weighted.

The char yields shown in Table 3 was calculated as:

Char yield $=\frac{\text { Mass of collected char }}{\text { Mass of feedstock }} \times 100$.

The collected char was the sum of the char in the reservoir and in the auxiliary tank. The gas yield was calculated as the ratio between the volume of the dry flow measured
Table 2 Experimental condition in gasification tests

\begin{tabular}{lllllllll}
\hline Test & Feedstock & $\begin{array}{l}\text { Feed- } \\
\text { ing rate } \\
(\mathrm{kg} / \mathrm{h})\end{array}$ & Air $(\mathrm{kg} / \mathrm{h})$ & $\begin{array}{l}\text { Steam }(\mathrm{kg} / \mathrm{h}) \\
\text { Equiva- }\end{array}$ & $\begin{array}{l}\text { Steam/biomass } \\
\text { lence } \\
\text { ratio }\end{array}$ & $\begin{array}{l}\text { Rotational } \\
\text { speed } \\
(\mathrm{rpm})\end{array}$ & $\begin{array}{l}\text { Elec- } \\
\text { trical } \\
\text { heaters }\end{array}$ \\
\hline $\mathrm{I}$ & $\mathrm{AD}^{\mathrm{a}}$ & 14.0 & 15.0 & 0.26 & 2 & On \\
$\mathrm{II}$ & $\mathrm{AD}^{\mathrm{a}}$ & 21.8 & 23.4 & 0.26 & 2 & On \\
$\mathrm{III}$ & $\mathrm{AD}^{\mathrm{a}}$ & 22.3 & 28.4 & 0.30 & 2 & On \\
$\mathrm{IV}$ & $\mathrm{AD}^{\mathrm{a}}$ & 22.8 & 20.6 & 0.22 & 1 & On \\
$\mathrm{V}$ & $\mathrm{AD}^{\mathrm{a}}$ & 27.5 & 45.3 & & 0.39 & 1 & Off \\
$\mathrm{VI}$ & $\mathrm{Mix}^{\mathrm{b}}$ & 18.8 & 28.2 & & 0.30 & & 1 & Off \\
$\mathrm{VII}$ & $\mathrm{Mix}^{\mathrm{b}}$ & 19.5 & 26.9 & 8.4 & 0.29 & 0.43 & 1 & On \\
\hline
\end{tabular}

\footnotetext{
${ }^{\mathrm{a}}$ Anaerobic digestate

${ }^{\mathrm{b}} 60 \mathrm{wt} \%$ digestate e $40 \mathrm{wt} \%$ almond shells
} 
Table 3 Results of gasification tests

\begin{tabular}{llrrrrrrrrrr}
\hline Test & $\begin{array}{l}\text { Gas yield } \\
\left(\mathrm{Nm}^{3} / \mathrm{kg}_{\text {feed }}\right)\end{array}$ & \multicolumn{1}{c}{$\mathrm{H}_{2}$} & $\mathrm{CO}$ & $\mathrm{CO}_{2}$ & $\mathrm{CH}_{4}$ & $\mathrm{C}_{2} \mathrm{H}_{6}$ & $\mathrm{~N}_{2}$ & LHV $\left(\mathrm{MJ} / \mathrm{Nm}^{3}\right)$ & $\begin{array}{l}\text { Cold gas } \\
\text { efficiency }\end{array}$ & $\begin{array}{l}\text { Char/biomass } \\
\tau \text { resid. } \\
\text { char } \\
(\mathrm{min})\end{array}$ \\
\hline I & 1.02 & 9.7 & 10.4 & 13.3 & 4.0 & 1.3 & 61.3 & 4.61 & 0.27 & 0.39 & 13 \\
II & 1.00 & 9.4 & 9.9 & 14.0 & 3.3 & 0.9 & 62.5 & 4.03 & 0.26 & 0.38 & 8 \\
III & 1.38 & 9.6 & 11.3 & 13.7 & 2.9 & 0.7 & 61.8 & 3.97 & 0.36 & 0.41 & 8 \\
IV & 0.99 & 11.9 & 13.6 & 12.9 & 4.5 & 1.3 & 55.7 & 5.46 & 0.36 & 0.39 & 8 \\
V & 1.40 & 9.3 & 11.1 & 13.8 & 2.9 & 0.6 & 62.3 & 3.84 & 0.47 & 0.40 & 7 \\
VI & 1.67 & 10.4 & 11.6 & 16.5 & 3.8 & 0.7 & 57.1 & 4.40 & 0.55 & 0.37 & 10 \\
VII & 1.78 & 11.2 & 10.9 & 15.0 & 2.8 & 0.7 & 59.4 & 4.02 & 0.17 & 0.31 & 9 \\
\hline
\end{tabular}

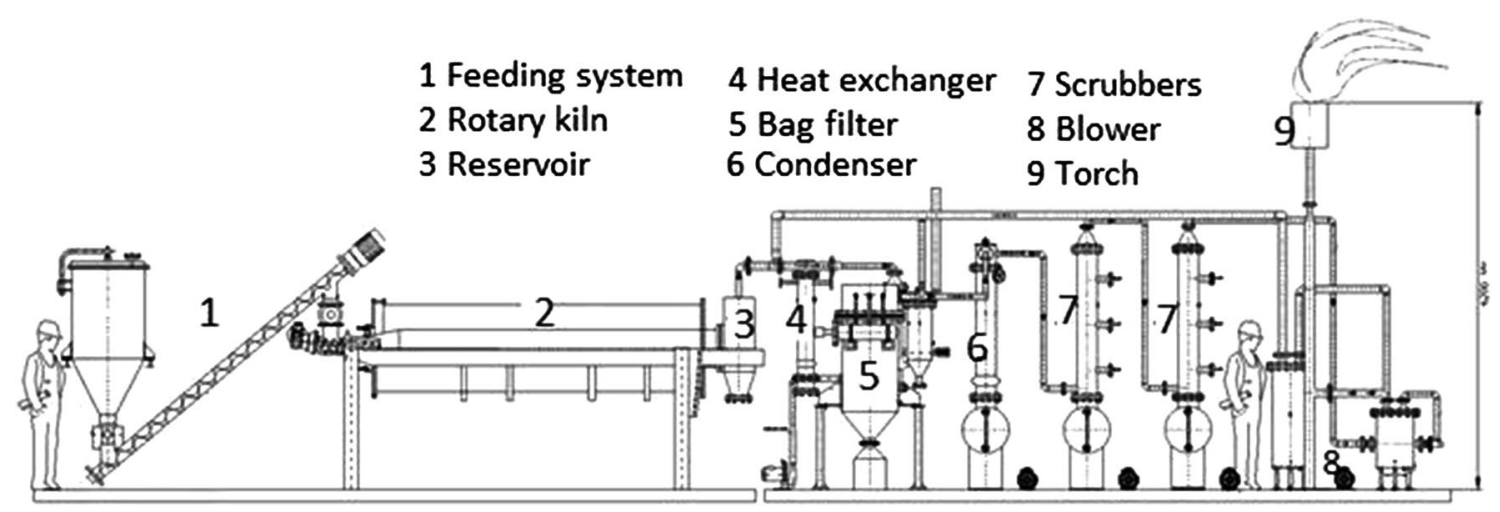

Fig. 1 Rotary kiln layout of the $20 \mathrm{~kg} / \mathrm{h}$ pilot plant

by the gas meter, and the mass of feedstock. The mean residence time (MRT) of the solid in the kiln was calculated by the following formula proposed by Liu and Specht [31]:

$\mathrm{MTR}_{\text {solid }}=\frac{\text { Volume of kiln hold up }}{\text { Feedstock volumetric rate }}$.

The equivalence ratio is the ratio between the amount of air supplied to the reactor to drive the feedstock gasification and the amount of air necessary to burn it quantitatively. To calculate this amount of air, the pseudo chemical formula $\mathrm{C}_{\alpha} \mathrm{H}_{\beta} \mathrm{O}_{\chi} \mathrm{N}_{\delta} \mathrm{S}_{\varepsilon} \mathrm{Cl}_{\phi}$ was considered on dry ash free basis. It was calculated keeping into account the ultimate analysis data presented in Table 1. The combustion reaction was assumed according to the following equation [32]:

$$
\begin{array}{r}
\mathrm{C}_{\alpha} \mathrm{H}_{\beta} \mathrm{O}_{\gamma} \mathrm{N}_{\delta} \mathrm{S}_{\varepsilon} \mathrm{Cl}_{\theta}+(2 \alpha+\beta / 2+2 \delta+2 \varepsilon-\gamma) / 2\left(\mathrm{O}_{2}+3.76 \mathrm{~N}_{2}\right. \\
\rightarrow \alpha \mathrm{CO}_{2}+(\beta / 2) \mathrm{H}_{2} \mathrm{O}+\delta \mathrm{NO}_{2}+\varepsilon \mathrm{SO}_{2}+9 \mathrm{HCl} \\
+1.88(2 \alpha+\beta / 2+2 \delta+2 \varepsilon-\gamma) \mathrm{N}_{2}
\end{array}
$$

based on such reaction, to burn quantitatively $1 \mathrm{~kg}$ of dry digestate and almond shell, $4.6 \mathrm{~kg}$ and $5.8 \mathrm{~kg}$ of air are, respectively required; $5.1 \mathrm{~kg}$ of air are instead necessary to burn quantitatively the dry mixture $60: 40 \mathrm{wt} \%$ of digestate and almond shells.

The cold gas efficiency (CGE) was calculated as ratio between the output power of the gas and the total of thermal power inputs:

Cold gas efficiency $=\frac{\mathrm{LHV}_{\text {gas }} \times \text { gas yield }}{\mathrm{LHV}_{\text {biomass }}+\frac{P_{\mathrm{el}}+P_{\mathrm{t}}}{\dot{m}}}$,

where the term at denominator $\left(P_{\mathrm{el}}+P_{\mathrm{t}}\right) / \dot{m}$ is the ratio between the total power, electrical and thermal required to, respectively, heat the reactor and produce steam, and the biomass feeding rate (Fig. 1).

\section{Simulation study}

A simulation study was carried out by the commercial software CHEMCAD [33]. The goal of the simulation was the energetic assessment of new plant designs that could increases the efficiency of the process. The chemical species of the simulation are: $\mathrm{N}_{2}, \mathrm{O}_{2}, \mathrm{CO}, \mathrm{CO}_{2}, \mathrm{C}, \mathrm{H}_{2}, \mathrm{CH}_{4}$, $\mathrm{H}_{2} \mathrm{O}, \mathrm{C}_{2} \mathrm{H}_{6}, \mathrm{CaO}$. Elemental carbon and calcium oxide were chosen to simulate the organic fraction of the char and the 
Fig. 2 Conceptual maps of simulations to increase the CGE of the process



ash, respectively. Soave-Redlich-Kwong model was set for Global K and for Global Enthalpy models. The ideal gas heat capacity followed the DIPPR (Design Institute for Physical Property Data) equation.

Conceptual map of simulations is shown in Fig. 2. In a combined heat and power process the syngas is burnt. Therefore, the combustion of the experimental syngas was simulated by a unit where product rates and thermodynamic state is calculated by the minimization of the Gibbs free energy. The exhaust gas was used to overheat, ideally by an indirect heat exchanger, the gasification reactor to increase the gasification temperature and the cold gas efficiency in those cases where a low gasification temperature was observed. The gasification reactor calculates the product rates and thermodynamic state minimizing the Gibbs free energy. An exploited second option, for the exhaust gas from syngas combustion, was the production/overheating of steam and the air preheating for the process.

\section{Results and discussion}

\section{Experimental study results}

The experimental conditions of gasification tests are reported in Table 2. All considered parameters were selected based on author's experience. In particular, the conditions corresponding to tests I-VI were adopted to preliminarily identify the process parameters at which the considered feedstocks gasification could be expected to proceed under autothermal conditions. The conditions corresponding to test VII were included in the experimental test plan to evaluate possible improvements in the produced gas properties by means of steam injection.

In line with the need to carry out the gasification process under autothermal conditions, except for test I, the feedstock feeding rate was set at maximum power to maximize the thermal input to the gasifier. Test I was operated at reduced feeding rate to have a term of comparison.

Biomass flow rate was quite reproducible in test II, III, IV, VI and VII. In test V the mass flow rate was about 35\% higher than the nominal rate of $20 \mathrm{~kg} / \mathrm{h}$. This deviation was purposely obtained by a higher working of bridge-break vibrator during this test to have higher thermal input. The air flow rate was set to have an equivalence ratio in the range suitable for biomass gasification (0.2-0.4). Rotational speed was set at 1 and $2 \mathrm{rpm}$ to obtain a Froude number in the range $10^{-4}-10^{-2}$. This condition is necessary to have a rolling motion of bed in the rotary kiln with good mixing of the bed material and satisfactory heat exchange [21].

When biomass gets into the kiln, the pyrolysis occurs. It is the first step of the process, the high temperature drives production of gaseous molecules such as carbon monoxide, hydrogen, carbon dioxide, methane, light hydrocarbons $\mathrm{C}_{2}-\mathrm{C}_{3}$, together with steam, organic volatile molecules and inorganic vapours. As known the char solid product of the pyrolysis has a carbonaceous structure and generally it also preserves the ash of the starting material. Pyrolysis is strictly related to the heat transfer between the reaction environment and the feedstock. Usually, it is complete in about 2 min [34]. Considering that the average residence time of char in the rotary kiln is about $9 \mathrm{~min}$ (Table 3 ) and that the kiln length is $3 \mathrm{~m}$, it can be easily calculated that pyrolysis is theoretically complete when the solid is at $0.66 \mathrm{~m}$ from the head of the reactor. From here onwards char gasification happens, that is carbon dioxide, steam and hydrogen react with the carbon of the char according to the following reactions:

$\mathrm{C}+\mathrm{CO}_{2}=2 \mathrm{CO}$ Boudouard

$\mathrm{C}+\mathrm{H}_{2} \mathrm{O}=\mathrm{CO}+\mathrm{H}_{2}$ char steam gasification,

$\mathrm{C}+2 \mathrm{H}_{2}=\mathrm{CH}_{4}$ char methanation.

The kinetic of these chemical reactions is appreciably fast when the temperature is in the range $700-900^{\circ} \mathrm{C}$. From a thermochemical point of view, these reactions are globally endothermic; therefore, thermal energy is required to sustain the gasification temperature. In the case of rotary kiln considered in this work, thermal energy can be provided by the electrical heaters of the kiln; or by combustion of carbon monoxide, methane, hydrogen, and light hydrocarbons, that develop during the thermochemical conversion process, with the oxygen in the air used as gasification agent, according to the following chemical reactions:

$\mathrm{CO}+0.5 \mathrm{O}_{2}=\mathrm{CO}_{2}$,

$\mathrm{CH}_{4}+2 \mathrm{O}_{2}=\mathrm{CO}_{2}+2 \mathrm{H}_{2} \mathrm{O}$,

$\mathrm{H}_{2}+0.5 \mathrm{O}_{2}=\mathrm{H}_{2} \mathrm{O}$, 


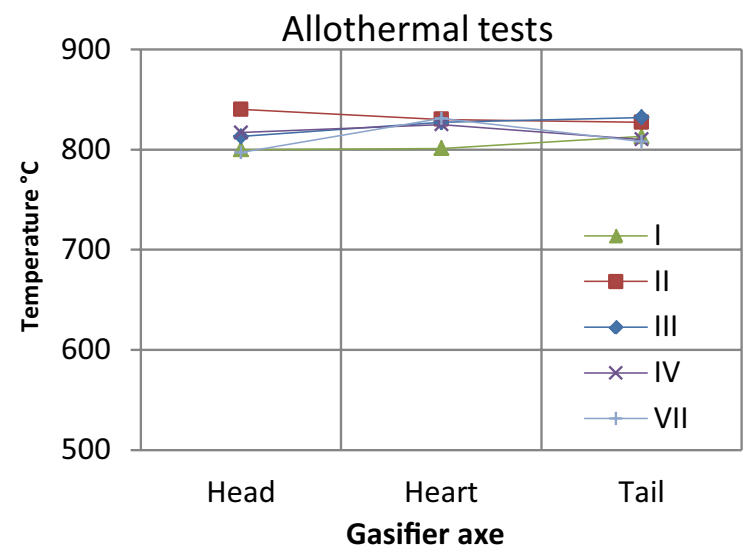

(a)

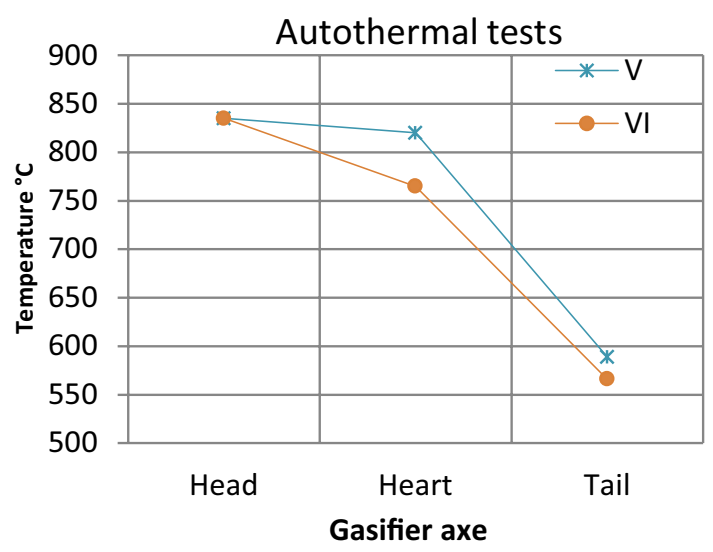

(b)

Fig. 3 Axial temperature profile in the rotary kiln gasifier in: a allothermal and $\mathbf{b}$ autothermal runs. Shown temperature is calculated as an average over the steady-state 5 -h tests

$$
\mathrm{C}_{x} \mathrm{H}_{y}+\left(x+\frac{y}{4}\right) \mathrm{O}_{2}=x \mathrm{CO}_{2}+\left(\frac{y}{2}\right) \mathrm{H}_{2} \mathrm{O} \text {. }
$$

The second option is preferable when an autothermal process is required for gas production in compliance with an economic feasibility of the process. Therefore, gasification tests were carried out trying to approach autothermal regime by air injection. In tests I, II, III, IV the equivalence ratio was varied between 0.22 and 0.30 , but the autothermal state was not achieved. To sustain the gasification temperature in the range $800-830{ }^{\circ} \mathrm{C}$ additional heating was then supplied by the electrical heaters of the kiln. As shown in Fig. 3a, the axial temperature profile resulted thus approximatively constant. In tests $\mathrm{V}$ and VI autothermal condition was reached by the following methods: in test $\mathrm{V}$ equivalence ratio was increased up to 0.39 and the digestate mass rate up to $27.5 \mathrm{~kg} / \mathrm{h}$, in this way higher thermal power was delivered to sustain the process; in test VI digestate was cogasified with almond shells at a mixing ratio of 60:40 wt $\%$ (Table 2). The mixture had an ash content of about $20 \mathrm{wt} \%$, and a heating value of about $15 \mathrm{MJ} / \mathrm{kg}$. These values made the gasification of the mixture more favourable compared to the gasification of digestate alone. As an inert material, ash had to be heated up to the process temperature, moreover the higher heating value of the mixture allowed to obtain higher thermal energy. In confirmation of what discussed, the cold gas efficiency of co-gasification test VI resulted indeed higher, 0.55 , compared to digestate gasification test $\mathrm{V}, 0.47$ (Table 3).

In the autothermal tests, $\mathrm{V}$ and VI, the axial temperature profile is markedly decreasing (Fig. 3b). Very probably, the air that gets at the head of the kiln, favoured the fast and exothermic combustion reactions (8-11). The temperature drop between the head and tail of the kiln was of about $250{ }^{\circ} \mathrm{C}$. From a mechanical point of view this drop could give thermal stress to the stainless steel of the kiln. Moreover, the tail temperature slows down the kinetics of the gasification reactions of char (5-7) [35, 36]. Therefore, technical measures to increase the gasification temperature of the tail of the reactor should be taken in account and will be proposed in the simulation study.

As could be expected, the experimental gas yields were found to increases with the equivalence ratio. Specifically, value rising: from 0.99 to $1.40 \mathrm{Nm}^{3} / \mathrm{kg}$ were observed, on average bases, when increasing the equivalence ratio from 0.22 to 0.39 (Tables 2, 3). A higher gas yield was obtained when the digestate was co-gasified with almond shells, as a result of the higher organic matter content (volatile plus fixed carbon) of this latter compared to the digestate (Table 1). Regarding the produced gas, its composition results in all tests quite close to that of the syngas from lignocellulosic biomass $[37,38]$. Molar ratio between $\mathrm{H}_{2}$ and $\mathrm{CO}$ is always lower than 1, except in test VII where it reached the value of 1 . In this tests steam was also injected to the reactor. Most likely, steam reacted with carbon monoxide according to the water gas shift reaction, and with methane for its reforming:

$\mathrm{CO}+\mathrm{H}_{2} \mathrm{O}=\mathrm{CO}_{2}+\mathrm{H}_{2}$,

$\mathrm{CH}_{4}+\mathrm{H}_{2} \mathrm{O}=3 \mathrm{H}_{2}+\mathrm{CO}$.

Moreover, steam reacted with char according to reaction (6). The overall result was thus an increase of the $\mathrm{H}_{2}$ content in the produced gas.

To give an example of the evolution of syngas composition, in Fig. 4 the syngas components are shown as function of time for tests V. The transient status lasted for about $1 \mathrm{~h}$. After this time, the steady state condition is approached. 


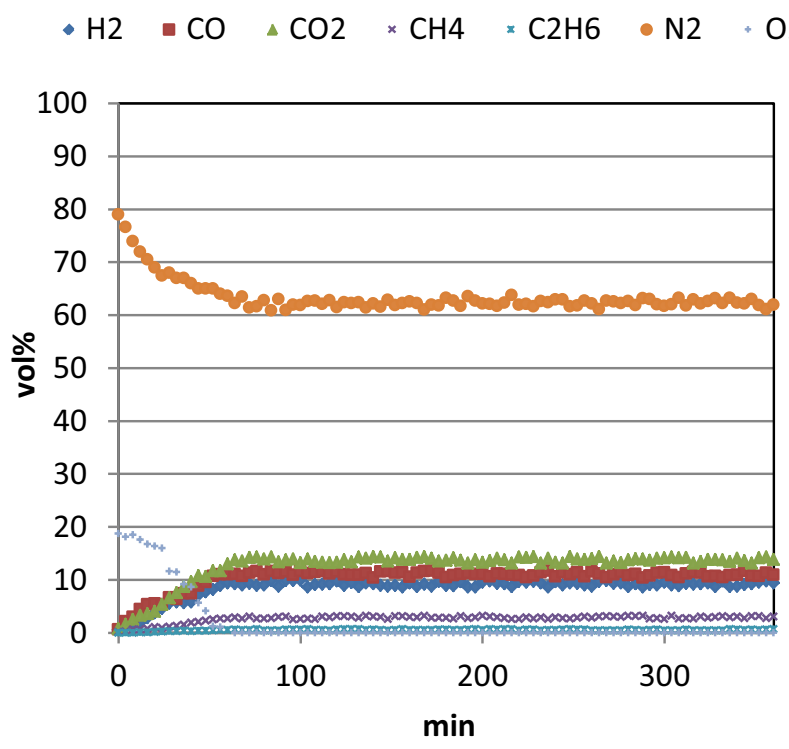

Fig. 4 Syngas composition vs time in test V

Due to the use of nitrogen to the sealing of the kiln and to the feeding system, the nitrogen content in syngas ranges from 56 to $62 \mathrm{vol} \%$. It is higher compared to lignocellulosic biomass gasification by air where it is typically about 50 vol\% [39-41]. Obviously, it affects negatively the gas heating value as combustible molecules are diluted by nitrogen. It should be minded that lower heating value of syngas for internal combustion engine usually is higher than $4 \mathrm{MJ} / \mathrm{Nm}_{\mathrm{dry}}^{3}$ [42]. Lower heating value causes an efficiency derating of the downstream devices.

The filling factor of a rotary kiln, i.e., the ratio between the volume of the advancing solid bed and the reactor volume is generally between 0.1 and 0.2 . This range complies with one of the conditions that assure the rolling motion of granular solid in the kiln, that radially ensures a good mixing and provides favourable conditions for the heat transfer in thermochemical processes [21, 43]. Considering the low filling factor, a lighter interaction between the process gas and char occurs compared to other gasifier such as downdraft or fluidized bed gasifier. Due to this aspect, gas yields and the yield of residual char are, respectively lower and higher than that observed in other gasification reactors $[19,20]$.

In tests $\mathrm{I}-\mathrm{V}$, the ratio char/digestate is about 0.4 . It is reasonably higher than the ash content of digestate (32\%). The lowest ratio char/biomass was 0.31 , obtained in test VII, when digestate was co-gasified with almond shells and when the gasifying mixture was a mix of air and steam. Very probably, steam reacted according to reaction (6), promoting char gasification. As proof of this, the gas yield in test VII was the highest. From a visual inspection, both char from digestate pellets and almond shells were black, the shape of the starting biomass was roughly preserved. Fragmentation and comminution phenomena occurred during the motion along the kiln, majorly for pellets compared to shells.

In test VII electrical heaters of the kiln were switched on to sustain the process, moreover an LPG boiler was used to produce steam that was injected into the kiln at about $200^{\circ} \mathrm{C}$. Definitively, the cold gas efficiency of this test was 0.17 , computing of the electrical power of the heaters and the boiler thermal power.

Globally, in the case of digestate gasification, the best energetic performance expressed as cold gas efficiency was 0.47 , achieved in test V. An improvement in the energetic performance was obtained when digestate was co-gasified with almond shells at $40 \mathrm{wt} \%$. In fact, in test VI the cold gas efficiency increased up to 55\%. In the other tests the power required to heat the reactor and to produce the required amount of steam, negatively affected the energetic balance of the process.

\section{Simulation study results}

According to data presented in Fig. 3b, in tests V and VI a decrease in the temperature profile along the rotary kiln reactor was observed. In a process to be carried out at industrial scale, such a circumstance would be a drawback, certainly a cause of reduced process performance. To remove such imbalance and try to ensure a more uniform temperature profile along the entire length of the reactor, a simulation study was carried out to evaluate the effect of possible process implementations. The following layout was investigated by CHEMCAD commercial simulation software.

It was supposed that the syngas with molar composition and volumetric rate of tests $\mathrm{V}$ and VI are burnt by air, such in a combined heat and power production process occurs. The exhaust gas exchanges indirectly heat with gasification stream in. This is composed by the char and gas computable from Tables 2 and 3 of experimental activity and explicated in Tables 4 and 5. The exchanged heat from the exhaust gas into the gasification stream in provides energy for the advancement of the process and to cover temperature drop. Tables 4 and 5 summarize the input and output streams to the gasification tail module and to the shell crossed by the exhaust gas.

It should be underlined that the gasification tail temperature increases to 790 and $761{ }^{\circ} \mathrm{C}$ for tests V and VI, respectively, covering the temperature drop that was experimentally observed (Fig. 3b). Moreover a higher carbon conversion was computed that means a higher cold gas efficiency for the gasification tests. In fact it was 0.64 and 0.72 for tests V and VI, respectively (Fig. 5). 
Table 4 Input and output streams to the tail of gasifier unit and to the indirect heat exchanger for test $\mathrm{V}$

\begin{tabular}{|c|c|c|c|c|c|c|c|c|}
\hline & \multicolumn{4}{|l|}{ Test V } & \multicolumn{4}{|l|}{ Test VI } \\
\hline & $\begin{array}{l}\text { Gasification } \\
\text { stream in }\end{array}$ & $\begin{array}{l}\text { Gasification } \\
\text { stream out }\end{array}$ & Exhaust gas in & Exhaust gas out & $\begin{array}{l}\text { Gasification } \\
\text { stream in }\end{array}$ & $\begin{array}{l}\text { Gasification } \\
\text { stream out }\end{array}$ & Exhaust gas in & Exhaust gas out \\
\hline$T\left({ }^{\circ} \mathrm{C}\right)$ & 820 & 790 & 1151 & 900 & 765 & 761 & 1215 & 900 \\
\hline$P$ (bar) & 1 & 1 & 1 & 1 & 1 & 1 & 1 & 1 \\
\hline $\begin{array}{l}\text { Total flow } \\
\mathrm{kg} / \mathrm{h} \\
\left(\mathrm{Nm}^{3} / \mathrm{h}\right)\end{array}$ & 64.38 & 64.38 & $(83.63)$ & (83.63) & 49.60 & 49.60 & (73.12) & (73.12) \\
\hline Comp unit & $\mathrm{kg} / \mathrm{h}$ & $\mathrm{kg} / \mathrm{h}$ & mol frac $\%$ & mol frac $\%$ & $\mathrm{~kg} / \mathrm{h}$ & $\mathrm{kg} / \mathrm{h}$ & mol frac $\%$ & mol frac $\%$ \\
\hline $\mathrm{N}_{2}$ & 29.98 & 29.98 & 74.9 & 74.2 & 22.31 & 22.31 & 73.2 & 73.2 \\
\hline $\mathrm{O}_{2}$ & & & 4.0 & 4.0 & & & 4.0 & 4.0 \\
\hline $\mathrm{CO}$ & 5.34 & 10.13 & & & 4.53 & 10.27 & & \\
\hline $\mathrm{CO}_{2}$ & 10.43 & 9.35 & 13.3 & 13.3 & 10.13 & 7.47 & 14.3 & 14.3 \\
\hline $\mathrm{C}$ & 2.2 & 1.28 & & & 3.22 & 2.35 & & \\
\hline $\mathrm{H}_{2}$ & 0.32 & 0.83 & & & 0.29 & 0.73 & & \\
\hline $\mathrm{CH}_{4}$ & 0.80 & 0 & & & 0.85 & & & \\
\hline $\mathrm{H}_{2} \mathrm{O}$ & 6.20 & 4.00 & 7.8 & 7.8 & 4.1 & 2.58 & 8.6 & 8.6 \\
\hline $\mathrm{C}_{2} \mathrm{H}_{6}$ & 0.31 & 0 & & & 0.29 & 0 & & \\
\hline $\mathrm{CaO}$ & 8.8 & 8.8 & & & 3.73 & 3.73 & & \\
\hline
\end{tabular}

Table 5 Input and output streams for steam generation and air preheating

\begin{tabular}{llllllll}
\hline & Exhaust gas I & Exhaust gas II & Water & Steam & Exhaust gas III & Air & Heated air \\
\hline$T\left({ }^{\circ} \mathrm{C}\right)$ & 1174 & 930 & 20 & 700 & 779 & 20 & 700 \\
$P($ bar $)$ & 1 & 1 & 1 & 1 & 1 & 1 & 1 \\
Total flow & $(77.61)$ & $(77.61)$ & 8.4 & 8.4 & $(77.61)$ & 26.9 & 26.9 \\
$\mathrm{~kg} / \mathrm{h}$ & & & & & & & \\
$\left(\mathrm{Nm}^{3} / \mathrm{h}\right)$ & & & & & & & \\
$\mathrm{Comp} \mathrm{unit}$ & mol frac $\%$ & mol frac $\%$ & $\mathrm{~kg} / \mathrm{h}$ & $\mathrm{kg} / \mathrm{h}$ & $\mathrm{mol} \mathrm{frac} \%$ & $\mathrm{~mol} \mathrm{frac} \mathrm{\%}$ & $\mathrm{mol} \mathrm{frac} \%$ \\
$\mathrm{~N}_{2}$ & 74.0 & 74.0 & & & 74.0 & 79 & 79 \\
$\mathrm{O}_{2}$ & 4.0 & 4.0 & & & 4.0 & 21 & 21 \\
$\mathrm{CO}_{2}$ & 13.5 & 13.5 & & & 13.5 & & \\
$\mathrm{H}_{2} \mathrm{O}$ & 9.8 & 9.8 & 8.4 & 8.4 & 9.8 & & \\
\hline
\end{tabular}

Another simulation was carried out to evaluate the potentiality of increasing of cold gas efficiency in test VII. The syngas with molar composition and volumetric rate of tests VII is burnt by air in a combustor. The exhaust gas I exchanges heat with water to produce overheated steam. The exhaust gas II exchanges heat with air to heat it (Fig. 6).

Table 5 points out that the gasification agents for the test VII can be produced exploiting the latent heat of the exhaust gas from the syngas combustion. $8.4 \mathrm{~kg} / \mathrm{h}$ of steam are produced and overheated at $700{ }^{\circ} \mathrm{C}$ and $26.9 \mathrm{~kg} / \mathrm{h}$ of air are preheated up to $700{ }^{\circ} \mathrm{C}$. In the formula 4 , replacing that the thermal power term $P_{\mathrm{t}}$, for steam production, with zero, a cold gas efficiency of 0.35 is calculated.

\section{Conclusion}

In the present work, digestate gasification and its co-gasification with lignocellulosic biomass were investigated in a pilot scale rotary kiln with air and air/steam mixture. Digestate is a more problematic feedstock compared to lignocellulosic biomass, mainly because the produced digestate is a sludge that is not so easy to feed to a thermal plant; moreover, its relatively high ash and moisture contents, negatively affect the energy performance of the process. These feeding issues were overcome by drying and pelleting the digestate sludge. An improvement in the energy performance of the gasification process was observed when it was co-gasified with almond shell, in fact the cold gas efficiency increased from 0.47 to 0.55 . More in detail, increases in the syngas yields 


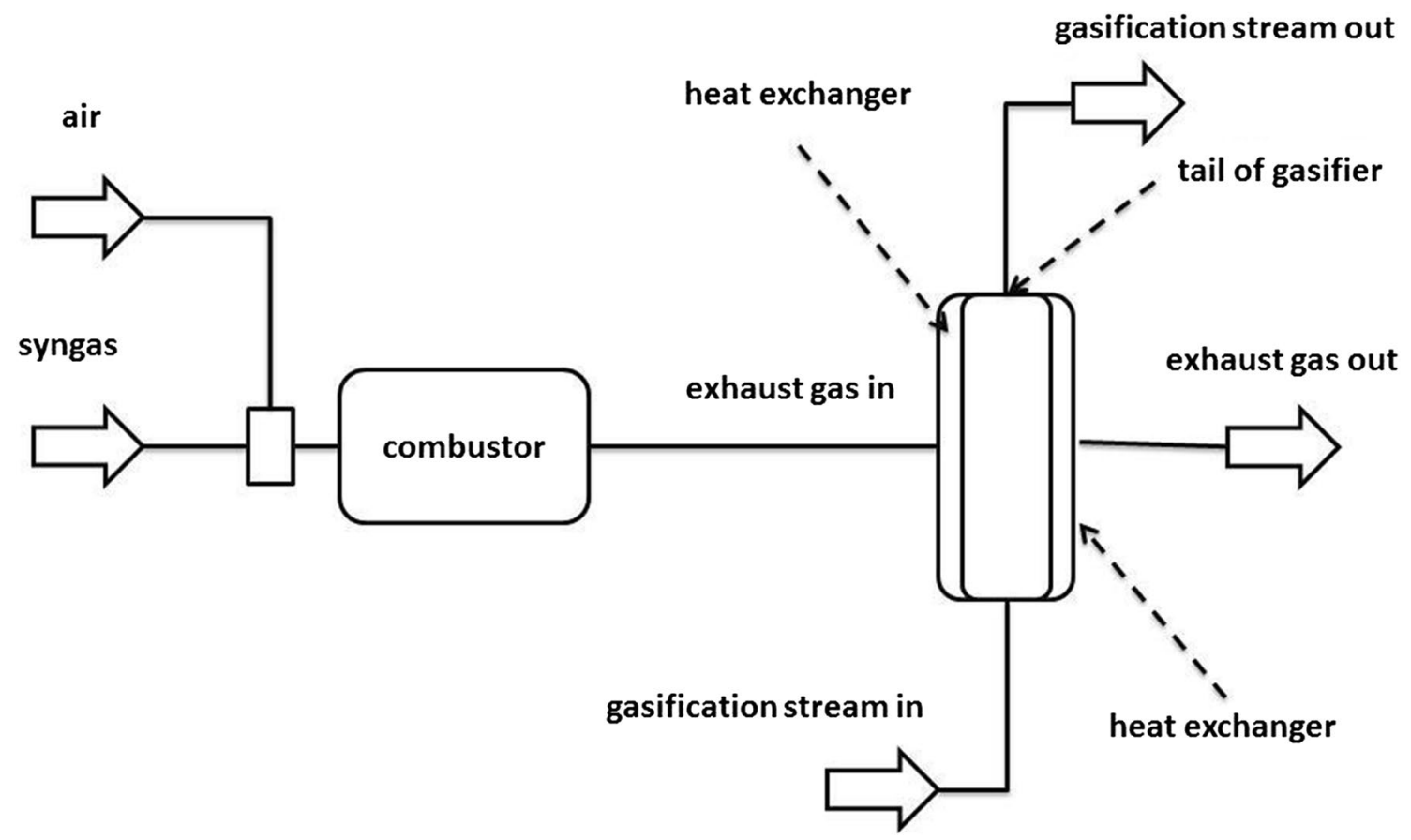

Fig. 5 Energy recovery layout for test V and VI

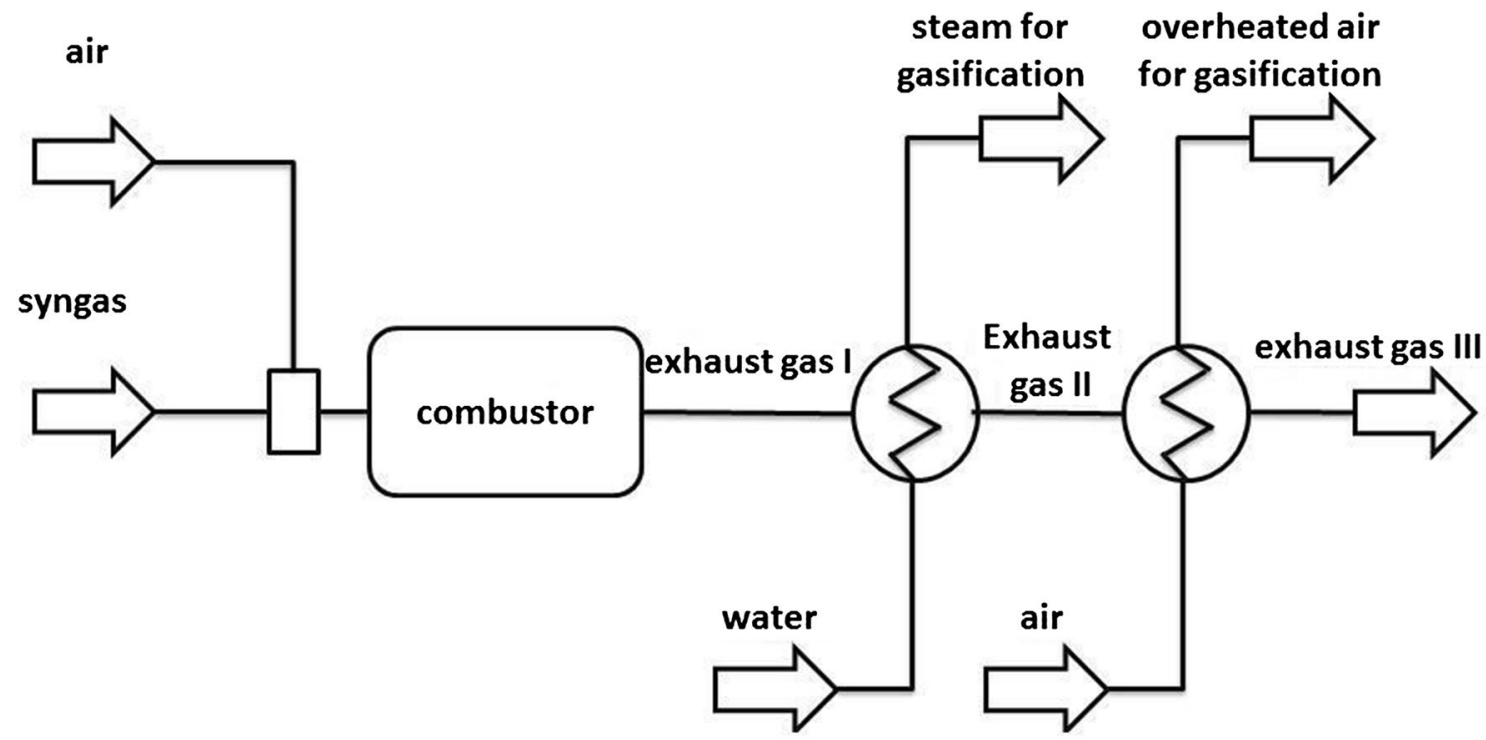

Fig. 6 Energy recovery layout for test VII

and heating values of $20 \%$ and $15 \%$, respectively, were observed in the co-gasification. Steam injection as gasifying agent increased the $\mathrm{H}_{2} / \mathrm{CO}$ ratio of the produced gas, by simultaneously reducing the yield of char and increasing the gas yield. However, under the tested condition, steam production and its overheating required power that reduced the cold gas efficiency to 0.17 . Globally, the rotary kiln reactor showed good operative reliability in the digestate gasification, even if some concerns should be considered: along the reactor axe, in the autothermal tests, a temperature drop of about $250{ }^{\circ} \mathrm{C}$ was detected. From a theoretical point of view a plant configuration to cover such temperature drop was identified in the heat recovery from the exhaust gas produced by the syngas combustion in the power device. Such a solution could easily be implemented by considering an indirectly heat exchange with the kiln in an annular 
chamber. By mean of this measure the cold gas efficiency could increase up to 0.64 and 0.72 in gasification and cogasification, respectively. In steam/air gasification, it was computed that gasification agent air and steam could be produced and heated up to process temperature by thermal exchange with the exhaust gas of syngas combustion. In this case the cold gas efficiency could increase up to 0.35 .

Acknowledgements This study was carried out under the aim of the National project "Veritas-Produzione di energia rinnovabile con il minimo Impatto da un Mix di Biomasse e rifiuti speciali non pericolosi attraverso processi innovativi”' (Cod EE01_00050) supported by the programme for R\&D Industria 2015. The authors wish to thank the Ministry of Economic Development (MiSE) and the Ministry of Education, University and Research (MIUR) for funding.

Open Access This article is distributed under the terms of the Creative Commons Attribution 4.0 International License (http://creativeco mmons.org/licenses/by/4.0/), which permits unrestricted use, distribution, and reproduction in any medium, provided you give appropriate credit to the original author(s) and the source, provide a link to the Creative Commons license, and indicate if changes were made.

\section{References}

1. Li, L., Peng, X., Wang, X., Wu, D.: Anaerobic digestion of food waste: a review focusing on process stability. Bioresour. Technol. 248, 20-28 (2018)

2. Komilis, D., Barrena, R., Grando, R.L., Vogiatzi, V., Sanchez, A., Font, X.: A state of the art literature review on anaerobic digestion of food waste: influential operating parameters on methane yield. Rev. Environ. Sci. Biotechnol. 16, 347-360 (2017)

3. Mao, C., Feng, Y., Wang, X., Ren, G.: Review on research achievements of biogas from anaerobic digestion. Renew. Sustain. Energy Rev. 45, 540-555 (2015)

4. Nguyen, H.H., Heaven, S., Banks, C.: Energy potential from the anaerobic digestion of food waste in municipal solid waste stream of urban areas in Vietnam. Int. J. Energy Environ. Eng. 5, 365-374 (2014)

5. Makádi, M., Tomócsik, A., Orosz, V.: Digestate: a new nutrient source-review. In: Kumar, S. (ed.) Biogas, pp. 295-310. InTech, Rijeka (2012)

6. Bustamante, M.A., Alburquerque, J.A., Restrepo, A.P., de la Fuente, C., Paredes, C., Moral, R., Bernal, M.P.: Co-composting of the solid fraction of anaerobic digestates, to obtain addedvalue materials for use in agriculture. Biomass Bioenergy 43, 26-35 (2012)

7. Siebert, S.: Secondary raw materials-compost and digestate from bio-waste. https://www.compostnetwork.info/downl $\mathrm{oad} /$ secondary-raw-materials-compost-digestate-bio-waste/. Accessed 05 May 2018

8. Wiśniewski, D., Gołaszewski, J., Białowiec, A.: The pyrolysis and gasification of digestate from agricultural biogas plant. Arch. Environ. Prot. 41(3), 70-75 (2015)

9. Chynoweth, D.P., Owens, J.M., Legrand, R.: Renewable methane from anaerobic digestion of biomass. Renew. Energy 22, 1-8 (2001)

10. Hossain, A.K., Serrano, C., Brammer, J.B., Omran, A., Ahmed, F., Smith, D.I., Davies, P.A.: Combustion of fuel blends containing digestate pyrolysis oil in a multi-cylinder compression ignition engine. Fuel 171, 18-28 (2016)
11. Pedrazzi, S., Allesina, G., Belló, T., Rinaldini, C.A., Tartarini, P.: Digestate as bio-fuel in domestic furnaces. Fuel Process. Technol. 130, 172-178 (2015)

12. Hübner, T., Mumme, J.: Integration of pyrolysis and anaerobic digestion-use of aqueous liquor from digestate pyrolysis for biogas production. Bioresour. Technol. 183, 86-92 (2015)

13. Monlau, F., Francavilla, M., Sambusiti, C., Antoniou, N., Solhy, A., Libutti, A., Zabaniotou, A., Barakat, A., Monteleone, M.: Toward a functional integration of anaerobic digestion and pyrolysis for a sustainable resource management. Comparison between solid-digestate and its derived pyrochar as soil amendment. Appl. Energy 169, 652-662 (2016)

14. Monlau, F., Sambusiti, C., Antoniou, N., Barakat, A., Zabaniotou, A.: A new concept for enhancing energy recovery from agricultural residues by coupling anaerobic digestion and pyrolysis process. Appl. Energy 148, 32-38 (2015)

15. Biederman, L.A., Stanley Harpol, W.: Biochar and its effects on plant productivity and nutrient cycling: a meta-analysis. GCB Bioenergy 5, 202-214 (2013)

16. Hilten, R.N., Das, K.C.: Comparison of three accelerated aging procedures to assess bio-oil stability. Fuel 89, 2741-2749 (2010)

17. Ringer, M., Putsche, V., Scahill, J.: Large-scale pyrolysis oil production: a technology assessment and economic analysis. Technical Report NREL/TP-510-37779 (2006)

18. Nanna, F., Villone, A., Freda, C., Barisano, D., Agostini, R., Braccio, G., Cornacchia, G., Brandani, S.: Gasification of anaerobic digestate from mix of biomass residues, manures and MSW to combined heat and power production. In: Proceedings of 25th European Biomass Conference and Exhibition, Stockholm, 12-15 June (2017)

19. Chen, G., Guo, X., Cheng, Z., Yan, B., Dan, Z., Ma, W.: Air gasification of biogas-derived digestate in a downdraft fixed bed. Waste Manag. 69, 162-169 (2017)

20. Gnanendra, P.M., Ramesha, D.K., Dasappa, S.: Preliminary investigation on the use of biogas sludge for gasification. Int. J. Sustain. Energy 31(4), 251-267 (2012)

21. Boateng, A.: Rotary Kilns Transport Phenomena and Transport Processes. Butterworth-Heinemann by Elsevier, Oxford (2008)

22. Notarnicola, M., Cornacchia, G., De Gisi, S., Di Canio, F., Freda, C., Garzone, P., Martino, M., Valerio, V., Villone, A.: Pyrolysis of automotive shredder residue in a bench scale rotary kiln. Waste Manag. 65, 92-103 (2017)

23. Shi, H., Si, W., Li, X.: The concept, design and performance of a novel rotary kiln type air-staged biomass gasifier. Energies 67(9), 1-18 (2016)

24. Benanti, E., Freda, C., Lorefice, V., Braccio, G., Sharma, V.K.: Simulation of olive pits pyrolysis in a rotary kiln. Therm. Sci. 15, 145-158 (2011)

25. Barisano, D., Canneto, G., Nanna, F., Alvino, E., Pinto, G., Villone, A., Carnevale, M., Valerio, V., Battafarano, A., Braccio, G.: Steam/oxygen biomass gasification at pilot scale in an internally circulating bubbling fluidized bed reactor. Fuel Process. Technol. 141(1), 74-81 (2016)

26. Pinto, F., André, R.N., Carolino, C., Miranda, M., Abelha, P., Direito, D., Perdikaris, N., Boukis, I.: Gasification improvement of a poor quality solid recovered fuel (SRF). Effect of using natural minerals and biomass wastes blends. Fuel 117, 1034-1044 (2014)

27. D’Orazio, A., Rapagnà, S., Foscolo, P.U., Gallucci, K., Nacken, M., Heidenreich, S., Di Carlo, A., Dell'Era, A.: Gas conditioning in $\mathrm{H}_{2}$ rich syngas production by biomass steam gasification: experimental comparison between three innovative ceramic filter candles. Int. J. Hydrog. Energy 40, 7282-7290 (2015) 
28. Rapagnà, S., Spinelli, G.: Biomass gasification with dolomite and olivine particles as a bed inventory in presence of ceramic filters. Chem. Eng. Trans. 52, 289-294 (2016)

29. Aldas, R., Gutierrez, A., ten Hope, L., Oglesby, R.P.: Increasing renewable energy by almond shell gasification. Almond Biomass Characterization Report. http://www.energy.ca.gov/2016p ublic ation s/CEC-500-2016-056/CEC-500-2016-056.pdf. Accessed 05 May 2018.

30. Sharma, A., Terrell, E., Theegala, C.S.: Biomass gasification and physical analysis of plant biomass and agricultural waste products in Louisiana. Wood Fiber Sci. 49(3), 1-11 (2017)

31. Liu, X.Y., Specht, E.: Mean residence time and hold-up of solids in rotary kilns. Chem. Eng. Sci. 61, 5176-5181 (2006)

32. Jenkins, B.M., Baxter, L.L., Miles Jr., T.R., Miles, T.R.: Combustion properties of biomass. Fuel Process. Technol. 54, 17-46 (1998)

33. https://www.chemstations.com/. Accessed 10 Jan 2019

34. Jand, N., Foscolo, P.U.: Decomposition of wood particles in fluidized beds. Ind. Eng. Chem. Res. 44, 5079-5089 (2005)

35. SERI Staff Members. A survey of biomass gasification. Principles of Gasification, vol. II. NTIS US. SERI/TR-33-239, Ch. 7, pp. 179-211 (1979)

36. Xu, Q., Pang, S., Levi, T.: Reaction kinetics and producer gas compositions of steam gasification of coal and biomass blend chars, part 2: mathematical modelling and model validation. Chem. Eng. Sci. 66, 2232-2240 (2011)

37. Barisano, D., Freda, C., Nanna, F., Fanelli, E., Villone, A.: Biomass gasification and in-bed contaminants removal: performance of iron enriched olivine and bauxite in a process of steam $/ \mathrm{O}_{2}$ gasification. Bioresour. Technol. 118, 187-194 (2012)

38. Fanelli, E., Freda, C., Canneto, G., Barisano, D., Nanna, F., Braccio, G.: Experimentation of a down-draft gasifier coupled with an Internal Combustion Engine (ICE) for theoretical model validation. In: Proceedings of the 4th International Conference on biomass for energy, Kyiv, 22-24 September 2008

39. Reed, T.B., Das Golden, A.: Handbook of biomass-downdraft gasifier engine systems. SERIISP-271-3022 (1988). https:// www.nrel.gov/docs/legosti/old/3022.pdf. Accessed 05 May 2018.

40. Knoef, H.A.M.: Handbook Biomass Gasification, 1st edn. BTG, ISBN-10: 9081006819 (2005)

41. Reed, T.B.: Biomass gasification: principles and technology. Noyes Data Corp., 401 (1981)

42. Pradhan, A., Baredar, P., Kumar, A.: Syngas as an alternative fuel used in internal combustion engines: a review. J. Pure Appl. Sci. Technol. 5(2), 51-66 (2015)

43. Mellmann, J.: The transverse motion of solids in rotating cylinders-forms of motion and transition behavior. Powder Technol. 118, 251-270 (2001)

Publisher's Note Springer Nature remains neutral with regard to jurisdictional claims in published maps and institutional affiliations. 